\title{
The effect of phosphorus on the iron redox ratio, viscosity, and density of an evolved ferro-basalt
}

Received: 1 December 1993/Accepted: 15 February 1994

\begin{abstract}
Despite the abundant evidence for the enrichment of phosphorus during the petrogenesis of natural ferro-basalts, the effect of phosphorus on the physical properties of these melts is poorly understood. The effects of phosphorus on the viscosity, density and redox ratio of a ferro-basaltic melt have been determined experimentally. The viscosity measurements were obtained using the concentric cylinder method on a ferro-basaltic melt above its liquidus, at $1 \mathrm{~atm}$, in equilibrium with air and with $\mathrm{CO}_{2}$. The density measurements were performed using the double Pt-bob Archimedean method at superliquidus conditions under $1 \mathrm{~atm}$ of air. The redox ratio was obtained by wet chemical analysis of samples collected during physical property measurements. Phosphorus pentoxide reduces ferric iron in ferro-basaltic melt. The reduction due to $\mathrm{P}_{2} \mathrm{O}_{5}$ is much larger than that for most other oxide components in basaltic melts. A coefficient for the reduction of ferric iron has been generated for inclusion in calculation schemes. The effect of $\mathrm{P}_{2} \mathrm{O}_{5}$ on the viscosity is shown to be complex. The initial reduction of ferric iron with the addition of $\mathrm{P}_{2} \mathrm{O}_{5}$ results in a relatively small change in viscosity, while further addition of $\mathrm{P}_{2} \mathrm{O}_{5}$ results in a strong increase. The addition of
\end{abstract}

\section{J. Toplis $(\Delta)^{1}$}

Department of Geology, Wills Memorial Building,

University of Bristol, BS8 1RJ Bristol, England

D. B. Dingwell

Bayerisches Geoinstitut, Universität Bayreuth, D-95440 Bayreuth, Germany

G. Liboure ${ }^{1}$

Université de Nancy 1, JE DRED Magmas et Métaux, BP 239 , F-54506, Vandoeuvre-lès-Nancy, France, and GRGP-CNRS,

BP 20, F-54501 Vandoeuvre-lès-Nancy, France

Current address:

${ }^{1}$ Bayerisches Geoinstitut, Universität Bayreuth, D-95440 Bayreuth, Germany

Editorial responsibility: W. Schreyer phosphorus to a ferro-basaltic melt also reduces the density. A partial molar volume of $64.5 \pm 0.7 \mathrm{~cm}^{3} / \mathrm{mol}$ for $\mathrm{P}_{2} \mathrm{O}_{5}$ in this melt has been obtained at $1300^{\circ} \mathrm{C}$, yielding a volume of $12.9 \mathrm{~cm}^{3} / \mathrm{mol}$ per oxygen, consistent with a tetrahedral coordination for this high field strength cation. The effects of $\mathrm{P}_{2} \mathrm{O}_{5}$ on redox state, density and viscosity provide constraints on the structural role of phosphorus in these melts. The results suggest a complex interaction of phosphorus with the aluminosilicate network, and tetrahedral ferric iron. In light of the significant effects of phosphorus on the physical and chemical properties of ferro-basaltic liquids, and the extreme enrichments possible in these liquids in nature, the role of phosphorus in these melts should, in future, be considered more carefully.

\section{Introduction}

Due to the incompatible behaviour of $\mathrm{P}_{2} \mathrm{O}_{5}$ during the early stages of crystallization, and the relatively large solubility of $\mathrm{P}$ in basic melts (Watson 1979; Harrison and Watson 1984), phosphorus enrichment in natural basaltic magmas may reach the weight percent level before the saturation of a phosphate phase (Anderson and Greenland 1969; Leeman et al. 1976; Beswick and Carmichael 1978; Philpotts 1982). Enrichment of P to these levels will, however, only occur after extensive fractionation, and magmas enriched in phosphorus will necessarily also be rich in iron.

Even at these concentrations phosphorus is known to lower the liquidus temperature dramatically, cause the deflection of liquidus boundaries to lower silica content, and increase the liquid-liquid immiscibility gap in many simple and complex silicate systems (Wyllie and Tuttle 1964; Kushiro 1975; Watson 1976; Ryerson and Hess 1978, 1980; Visser and Koster van Groos 1979; Ryerson 1985; London et al. 1990, 1993; Toplis et al. 1994). Both the above experimental work, and spectroscopic studies (Nelson and Tallant 1984; 
Duprée et al. 1988; Mysen 1992; Gan and Hess 1992) suggest that the addition of $\mathrm{P}$ to silicate melts causes important, and complex changes in the silicate melt structure (see also Mysen 1988). These inferred structural changes may therefore also be expected to have important consequences for the physical properties of these silicate liquids. Furthermore, in iron-bearing systems recent studies suggest that $\mathrm{P}_{2} \mathrm{O}_{5}$ may also cause variations in the ratio of ferric and ferrous iron (Mysen 1992; Gwinn and Hess 1993). Variations in the ferric-ferrous ratio may result in significant changes in both the density and viscosity of iron-bearing silicate melts (Lange and Carmichael 1990; Dingwell 1991) and thus the addition of phosphorus to these melts may result in complex variations of the physical properties.

The effects of $\mathrm{P}_{2} \mathrm{O}_{5}$ on the physical and chemical properties of such iron-rich basaltic magmas are, however, poorly understood. Phosphorus does not appear in the commonly used calculation schemes of density (Lange and Carmichael 1990), or ferric-ferrous ratio (Sack et al. 1980; Kilinc et al. 1983), and it is simply summed with $\mathrm{SiO}_{2}$ for the calculation of viscosity (Bottinga and Weill 1972). In order to clarify this situation we have determined the effect of the addition of $\mathrm{P}_{2} \mathrm{O}_{5}$ on the ferric-ferrous ratio, viscosity and density of a melt of ferro-basaltic composition. Viscosity has been measured at two different oxygen fugacities (air and $\mathrm{CO}_{2}$ ) over a large superliquidus range of temperature, and density has been measured in air for the same melt composition containing up to $10 \mathrm{wt} \% \mathrm{P}_{2} \mathrm{O}_{5}$. This study provides data for the calculation of the partial molar volume and viscosity coefficient of $\mathrm{P}_{2} \mathrm{O}_{5}$ in basic magmas. However, the effect of phosphorus on the iron redox ratio must be considered carefully and taken into account when interpreting the variation of density and viscosity as a function of $\mathrm{P}_{2} \mathrm{O}_{5}$. The results have implications for petrogenetic processes involving the mass transport of crystals and melts in magma chambers, and may also be used to constrain models for the interaction of phosphorus with iron in ferro-basaltic melts.

\section{Experimental methods}

A phosphorus-free ferro-basaltic composition ( $\mathrm{SC} 4$, from Toplis et al. 1994) to which various quantities of $\mathrm{P}_{2} \mathrm{O}_{5}$ were added, was used in this study. The selected $\mathrm{P}$-free starting composition is an evolved basalt $\left[\mathrm{Mg}^{*} ; \mathrm{Mg} /\left(\mathrm{Mg}+\mathrm{Fe}_{\text {total }}\right)=0.37\right]$. This composition corresponds to a residual liquid obtained from crystallization experiments on a synthetic analogue of the basaltic dyke $\mathrm{C}$ of Brooks and Nielsen (1978), which was considered by those authors as a possible parental liquid for the exposed portion of the Skaergaard intrusion, and may be considered typical of many ferro-basaltic compositions. The starting materials for all experiments were synthetic glasses prepared from mixtures of reagent grade oxides and carbonates $\left(\mathrm{SiO}_{2}, \mathrm{TiO}_{2}\right.$, $\mathrm{Al}_{2} \mathrm{O}_{3}, \mathrm{Fe}_{2} \mathrm{O}_{3}, \mathrm{MgO}, \mathrm{CaCO}_{3}, \mathrm{Na}_{2} \mathrm{CO}_{3}, \mathrm{~K}_{2} \mathrm{CO}_{3}$ ). Phosphorus was added as $\mathrm{NH}_{4} \mathrm{PO}_{3}$. Oxide mixtures were fused directly for several hours at $1600^{\circ} \mathrm{C}$ in a $\mathrm{MoSi}_{2}$ box furnace in a $75 \mathrm{~cm}^{3}$ thinwalled $\mathrm{Pt}$ crucible. The bubble- and crystal-free products were then poured onto a cold steel plate and allowed to cool to room temperature. A new batch of $100 \mathrm{~g}$ of SC4 $\left(+\mathrm{P}_{2} \mathrm{O}_{5}\right)$ was synthesized before each viscosity experiment.

The shear viscosities were measured at $1 \mathrm{~atm}$ and temperatures in the range of 1200 to $1600^{\circ} \mathrm{C}$ in air and in $\mathrm{CO}_{2}$ using the concentric cylinder method. This apparatus, its mode of operation and modifications to the software and hardware have been discussed previously (Dingwell 1989). The viscometer head is a Brookfield $\mathrm{DV}-\mathrm{II}_{+}$(with a full-scale torque of $7.20 \times 10^{-2} \mathrm{~N}-\mathrm{m}$ ). The spindle and crucible are fabricated from $\mathrm{Pt}_{80} \mathrm{Rh}_{20}$, and the spindle geometry is identical to that described by Dingwell and Virgo (1987). The viscometry installation is capable of measurements in the range of 1 to $10^{6} \mathrm{dPas}$ (poise) with an accuracy of $5 \%$ at $2 \sigma$. The rotation rates used for the measurements vary with the viscosity of the sample between 5 and $100 \mathrm{rpm}$ with the consequence that higher viscosities are measured at lower strain rates. Nevertheless, it can be demonstrated that the measurements are Newtonian over the strain rate range investigated. This is fully consistent with estimates of the viscous relaxation timescales in silicate melts of these viscosities (Dingwell and Webb 1989). The first measurements were taken at approximately $1600^{\circ} \mathrm{C}$ and then carried out lowering the temperature, generally in steps of 25 or $50^{\circ} \mathrm{C}$, until either phase separation (e.g. crystallization, liquid-liquid unmixing) or an instrumental limit is reached. At the end of the lowest temperature measurement, the highest temperature condition is reoccupied and the comparison of first and last high temperature measurements serves as a check against instrumental drift. The measurements of viscosity are not absolute; rather the crucible, spindle, and head combination is calibrated against a standard of known viscosity. In this case SRM 711 lead-silicate glass was obtained from the National Institute of Standards and Testing (NIST) and used for this purpose.

Density determinations of the ferro-basaltic liquids were performed using the double Pt bob Archimedean technique. The apparatus is illustrated in Dingwell et al. (1988) and consists of a balance suspended above a vertically mobile high temperature furnace. The methods of operation and data gathering include the software modifications used by Dingwell (1992). Signals of bob buoyancy are electronically gathered, stored and later averaged. The method has been checked against $\mathrm{NaCl}$ and $\mathrm{Na}_{2} \mathrm{Si}_{2} \mathrm{O}_{5}$ melts. The determination of density using this device carries an imprecision of $0.2 \%$ at $1 \sigma$.

The melts were sampled by dipping an alumina rod into the melt which was then withdrawn and plunged into $\mathrm{H}_{2} \mathrm{O}$ for quenching. For viscosity measurements in air, samples were taken each $50^{\circ} \mathrm{C}$ in the range $1600^{\circ} \mathrm{C}$ to $1400^{\circ} \mathrm{C}$, and for experiments in $\mathrm{CO}_{2}$ samples were taken each $100^{\circ} \mathrm{C}$ in the range 1600 to $1400^{\circ} \mathrm{C}$. For density measurements samples were taken at the start of each set of measurements. Glass chips were mounted as polished sections for petrographic and electron microprobe analysis. Electron microprobe analyses were carried out using a CAMECA SX50 at the Bayerisches Geoinstitut using operating conditions of 20 or $30 \mathrm{~s}$ counting times, $12 \mathrm{nA}$ beam current, $15 \mathrm{kV}$ accelerating voltage, and a $10 \mu \mathrm{m}$ beam size. The following standards were used: albite $-\mathrm{Na}$; apatite $-\mathrm{P}$; orthoclase $-\mathrm{K}, \mathrm{Si} ; \mathrm{Fe}_{2} \mathrm{O}_{3}-\mathrm{Fe}$; wollastonite $-\mathrm{Ca}$; enstatite - Mg; $\mathrm{MnTiO}_{3}-\mathrm{Ti}$; spinel - Al. Results from the electron microprobe show no significant loss of alkalis, phosphorus or iron during the sampled high temperature part of viscosity measurements. Averages of run products are shown in Table 1 for viscosity determinations in air (Run no. MTV1-4), in $\mathrm{CO}_{2}$ (Run no. MTV6-9) and density determinations (Run no. MTD2-6). The remaining product was used for a determination of the ferric-ferrous ratio using wet chemical techniques at the Centre de Recherches Petrographiques et Geochimiques, Nancy.

\section{Results}

The effect of phosphorus on the iron redox ratio

Variations in density and viscosity due to the addition of phosphorus cannot be interpreted without a 
Table 1 Run compositions $(\mathrm{FeO}$ * total iron expressed as ferrous)

\begin{tabular}{|c|c|c|c|c|c|c|c|c|}
\hline \multirow{2}{*}{$\begin{array}{l}\text { Viscosity (Air) } \\
\text { Run no. } \\
\mathrm{SiO}_{2}\end{array}$} & \multicolumn{2}{|l|}{ MTV2 } & \multicolumn{2}{|l|}{ MTV4 } & \multicolumn{2}{|l|}{ MTV3 } & \multicolumn{2}{|l|}{ MTV1 } \\
\hline & $50.87(33)^{\mathrm{a}}$ & $51.96^{\mathrm{b}}$ & $50.66(30)$ & 52.27 & $50.52(30)$ & 54.14 & $47.42(11)$ & 51.99 \\
\hline $\mathrm{TiO}_{2}$ & $4.05(6)$ & 4.14 & $3.95(3)$ & 4.08 & $3.39(1)$ & 3.64 & $3.78(5)$ & 4.14 \\
\hline $\mathrm{Al}_{2} \mathrm{O}_{3}$ & $11.36(6)$ & 11.60 & $11.35(7)$ & 11.72 & $11.09(14)$ & 11.89 & $10.46(5)$ & 11.47 \\
\hline $\mathrm{FeO}^{*}$ & $14.20(31)$ & 14.51 & $13.90(14)$ & 14.35 & $12.61(25)$ & 13.52 & $13.40(20)$ & 14.69 \\
\hline $\mathrm{MgO}$ & $4.23(3)$ & 4.32 & $3.94(2)$ & 4.07 & $3.86(5)$ & 4.14 & $4.02(2)$ & 4.40 \\
\hline $\mathrm{CaO}$ & $9.62(12)$ & 9.83 & $9.60(5)$ & 9.91 & $8.48(10)$ & 9.08 & $9.38(8)$ & 10.28 \\
\hline $\mathrm{Na}_{2} \mathrm{O}$ & $3.06(3)$ & 3.12 & $2.98(2)$ & 3.08 & $2.85(15)$ & 3.05 & $2.36(13)$ & 2.58 \\
\hline $\mathrm{K}_{2} \mathrm{O}$ & $0.52(1)$ & 0.53 & $0.51(1)$ & 0.53 & $0.51(2)$ & 0.55 & $0.41(1)$ & 0.45 \\
\hline $\mathrm{P}_{2} \mathrm{O}_{5}$ & $0.09(1)$ & - & $2.40(6)$ & - & $5.62(18)$ & - & $9.54(6)$ & - \\
\hline Total & 98.00 & 100.0 & 99.29 & 100.0 & 98.93 & 100.0 & 100.77 & 100.0 \\
\hline \multicolumn{9}{|l|}{ Viscosity $\left(\mathrm{CO}_{2}\right)$} \\
\hline Run no. & \multicolumn{2}{|l|}{ MTV6 } & \multicolumn{2}{|l|}{ MTV9 } & \multicolumn{2}{|l|}{ MTV7 } & \multicolumn{2}{|l|}{ MTV8 } \\
\hline $\mathrm{SiO}_{2}$ & $50.84(41)$ & 51.01 & $49.61(46)$ & 50.94 & $49.04(37)$ & 51.16 & $47.15(10)$ & 51.36 \\
\hline $\mathrm{TiO}_{2}$ & $4.26(4)$ & 4.27 & $4.27(3)$ & 4.38 & $4.18(2)$ & 4.36 & $4.03(4)$ & 4.39 \\
\hline $\mathrm{Al}_{2} \mathrm{O}_{3}$ & $11.38(2)$ & 11.41 & $11.01(11)$ & 11.3 & $10.92(7)$ & 11.39 & $10.48(4)$ & 11.42 \\
\hline $\mathrm{FeO}^{*}$ & $15.05(34)$ & 15.09 & $14.73(48)$ & 15.12 & $14.46(5)$ & 15.08 & $13.90(22)$ & 15.14 \\
\hline $\mathrm{MgO}$ & $4.42(11)$ & 4.43 & $4.46(9)$ & 4.58 & $4.28(4)$ & 4.46 & $4.11(3)$ & 4.47 \\
\hline $\mathrm{CaO}$ & $10.18(23)$ & 10.21 & $10.04(17)$ & 10.31 & $9.76(3)$ & 10.18 & $9.49(3)$ & 10.34 \\
\hline $\mathrm{Na}_{2} \mathrm{O}$ & $3.01(4)$ & 3.02 & $2.81(3)$ & 2.88 & $2.66(2)$ & 2.77 & $2.24(1)$ & 2.44 \\
\hline $\mathrm{K}_{2} \mathrm{O}$ & $0.55(2)$ & 0.55 & $0.47(1)$ & 0.48 & $0.57(1)$ & 0.59 & $0.41(1)$ & 0.44 \\
\hline $\mathrm{P}_{2} \mathrm{O}_{5}$ & $0.04(1)$ & - & $2.51(4)$ & - & $4.92(14)$ & - & $9.45(7)$ & - \\
\hline Total & 99.73 & 100.0 & 99.91 & 100.0 & 100.79 & 100.0 & 101.26 & 100.0 \\
\hline \multicolumn{9}{|l|}{ Density (Air) } \\
\hline Run no. & \multicolumn{2}{|l|}{ MTD4 } & \multicolumn{2}{|l|}{ MTD6 } & \multicolumn{2}{|l|}{ MTD5 } & \multicolumn{2}{|l|}{ MTD2 } \\
\hline $\mathrm{SiO}_{2}$ & $50.86(16)$ & 51.19 & $49.72(38)$ & 51.02 & $50.64(19)$ & 53.11 & $47.42(11)$ & 51.99 \\
\hline $\mathrm{TiO}_{2}$ & $4.26(6)$ & 4.29 & $4.24(3)$ & 4.35 & $3.53(6)$ & 3.70 & $3.78(5)$ & 4.14 \\
\hline $\mathrm{Al}_{2} \mathrm{O}_{3}$ & $11.32(7)$ & 11.39 & $11.09(11)$ & 11.38 & $11.05(7)$ & 11.59 & $10.46(5)$ & 11.47 \\
\hline $\mathrm{FeO}^{*}$ & $14.89(17)$ & 14.99 & $14.72(25)$ & 15.11 & $13.49(16)$ & 14.15 & $13.40(20)$ & 14.69 \\
\hline $\mathrm{MgO}$ & $4.42(4)$ & 4.45 & $4.43(5)$ & 4.55 & $3.96(5)$ & 4.15 & $4.02(2)$ & 4.40 \\
\hline $\mathrm{CaO}$ & $10.06(9)$ & 10.13 & $9.98(19)$ & 10.24 & $9.15(11)$ & 9.60 & $9.38(8)$ & 10.28 \\
\hline $\mathrm{Na}_{2} \mathrm{O}$ & $3.05(5)$ & 3.07 & $2.80(3)$ & 2.87 & $2.85(4)$ & 2.99 & $2.36(13)$ & 2.58 \\
\hline $\mathrm{K}_{2} \mathrm{O}$ & $0.49(2)$ & 0.49 & $0.47(1)$ & 0.48 & $0.68(3)$ & 0.71 & $0.41(1)$ & 0.45 \\
\hline $\mathrm{P}_{2} \mathrm{O}_{5}$ & $0.08(3)$ & - & $2.50(5)$ & - & $5.66(23)$ & - & $9.54(6)$ & - \\
\hline Total & 99.43 & 100.0 & 99.95 & 100.0 & 101.01 & 100.0 & 100.77 & 100.0 \\
\hline
\end{tabular}

${ }^{a}$ Analyses by electron microprobe in weight percent. Number in parentheses represents standard deviation in terms of least $u n i t s$ cited

${ }^{b}$ Numbers in italics are the phosphorus free component of each composition, normalized to $100 \%$

knowledge of the effect of phosphorus on the ferricferrous ratio. Samples were therefore collected during physical property measurements, and although they were not rapidly quenched, they nevertheless provide quantitative information regarding the effect of $P$ on the ferric-ferrous ratio. Table 2 shows the experimental conditions and ferric-ferrous determination for each of the samples taken during the measurements of viscosity and density. The iron redox ratio, expressed as $\ln$ $\left(X \mathrm{Fe}_{2} \mathrm{O}_{3} / X \mathrm{FeO}\right)$, as a function of the mole percent $\mathrm{P}_{2} \mathrm{O}_{5}$ added, in air and in $\mathrm{CO}_{2}$, at various temperatures is shown in Fig. 1. The addition of $\mathrm{P}_{2} \mathrm{O}_{5}$ to this ferro-basaltic composition causes a reduction of ferric iron in both air and $\mathrm{CO}_{2}$ for all measured temperatures. The samples collected in air contain more ferric iron at lower temperature, consistent with the fact that conditions become more oxidized with respect to the fayalite-magnetite-quartz (FMQ) buffer, along with ferric-ferrous ratios have been shown to remain approximately constant (Kress and Carmichael 1988). In a $\mathrm{CO}_{2}$ atmosphere, the samples collected at 1400 and $1500^{\circ} \mathrm{C}$ have very similar oxidation states in agreement with the fact that the pure $\mathrm{CO}_{2}$ buffer remains approximately parallel to FMQ over the studied temperature range. Experiments at $1600^{\circ} \mathrm{C}$, in $\mathrm{CO}_{2}$, however, have a higher ferric-ferrous ratio, suggesting that oxidation has occurred due to the rapid diffusion of oxygen at this high temperature, and the relatively slow nature of the quench method. These data have therefore been disregarded for the discussion of the effect of phosphorus on the iron redox equilibria. We cannot discount the possibility that oxidation has also occurred in the other samples, particularly at high temperature, but at fixed temperature and $f_{\mathrm{O}_{2}}$ this will not be expected to change the conclusions concerning the effect of $\mathrm{P}_{2} \mathrm{O}_{5}$ in these melts. 
Table 2 Ferric-ferrous determinations

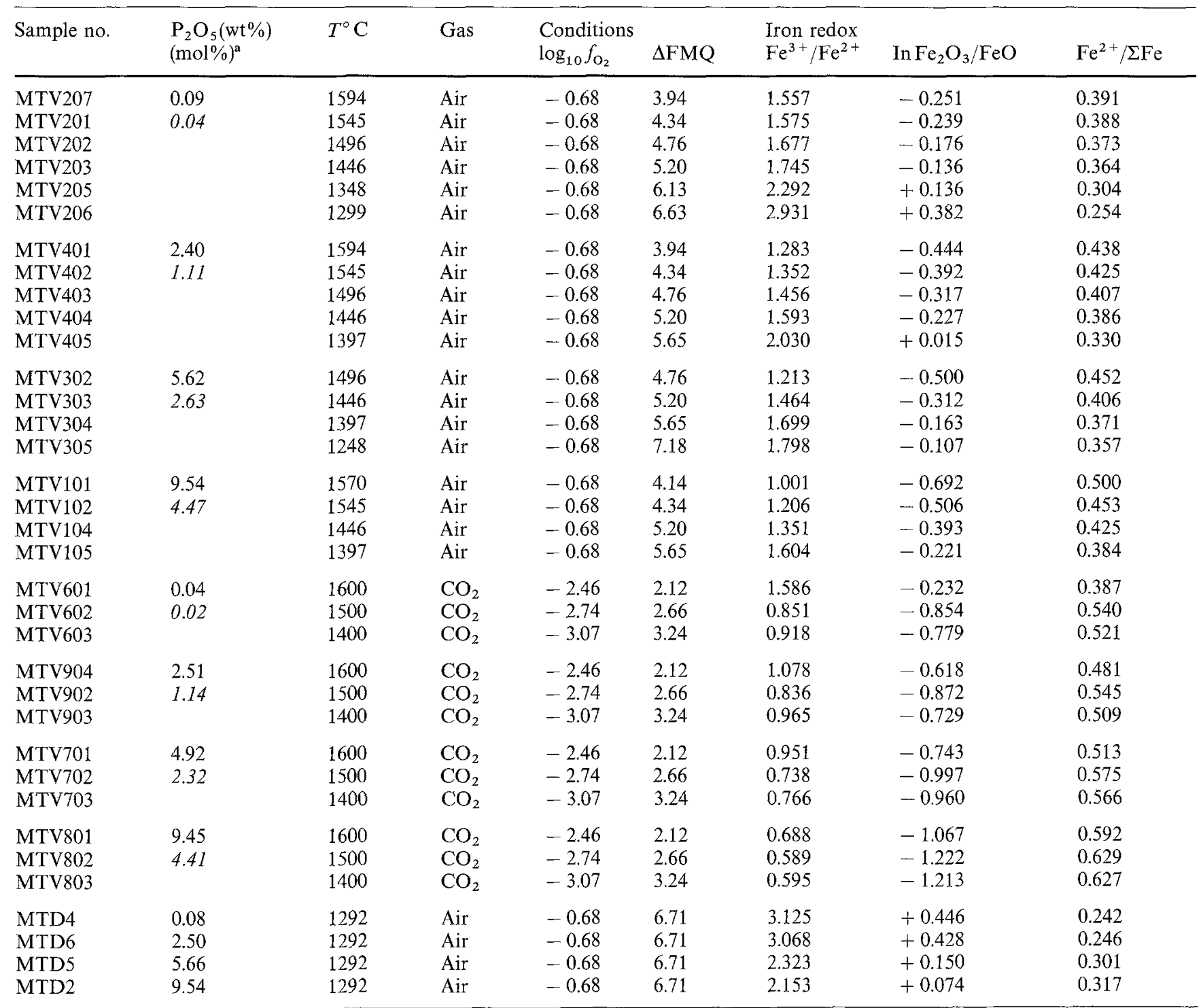

${ }^{a} \mathrm{P}_{2} \mathrm{O}_{5}$ contents shown as average values for each experiment in both wt $\%$ and mol $\%$. The standard deviations of these values are shown in Table 1

The $\ln \left(X_{\mathrm{Fe}_{2}} \mathrm{O}_{3} / X \mathrm{FeO}\right)$ along each isotherm decreases linearly with respect to molar $\mathrm{P}_{2} \mathrm{O}_{5}$ content within the uncertainties of the measurements (Fig. 1). In air, the gradient $\left(\Delta \ln \left(X \mathrm{Fe}_{2} \mathrm{O}_{3} / X \mathrm{FeO}\right) / \Delta X \mathrm{P}_{2} \mathrm{O}_{5}\right)$ varies from 5.4 to 6.9. A similar reduction of ferric iron by phosphorus has been observed for a calcium silicate melt containing $5 \mathrm{wt} \% \mathrm{Fe}_{2} \mathrm{O}_{3}$, in air (Mysen 1992). In $\mathrm{CO}_{2}$, the gradient ranges from 8.8 to 10.9 , suggesting that the reducing effect of phosphorus may become more important at lower oxygen fugacity, although more experiments are needed to verify this.

The effect of phosphorus on viscosity

The viscosity data for all experiments are presented in Table 3. Figs. $2 \mathrm{a}, \mathrm{b}$ show the temperature dependence of the viscosity of the studied compositions in air and $\mathrm{CO}_{2}$ respectively. The temperature dependence of the viscosity of silicate melts may be described by the Arrhenius Equation;

$\log _{10} \eta(\mathrm{dPa} s)=\log _{10} \eta_{0}(\mathrm{dPa} s)+2.303 E / R T$

where $\eta$ is the viscosity, $E$ is the activation energy, $R$ is the gas constant and $T$ is the absolute temperature. The curves shown in Fig. 2 are not linear and show an increasing departure from Arrhenian behaviour with falling temperature. This is consistent with the observation that systems poor in silica are in general non Arrhenian (e.g. Richet 1984). However, despite the departure from Arrhenian behaviour towards lower temperature, Eq. (1) satisfactorily describes the viscosity 


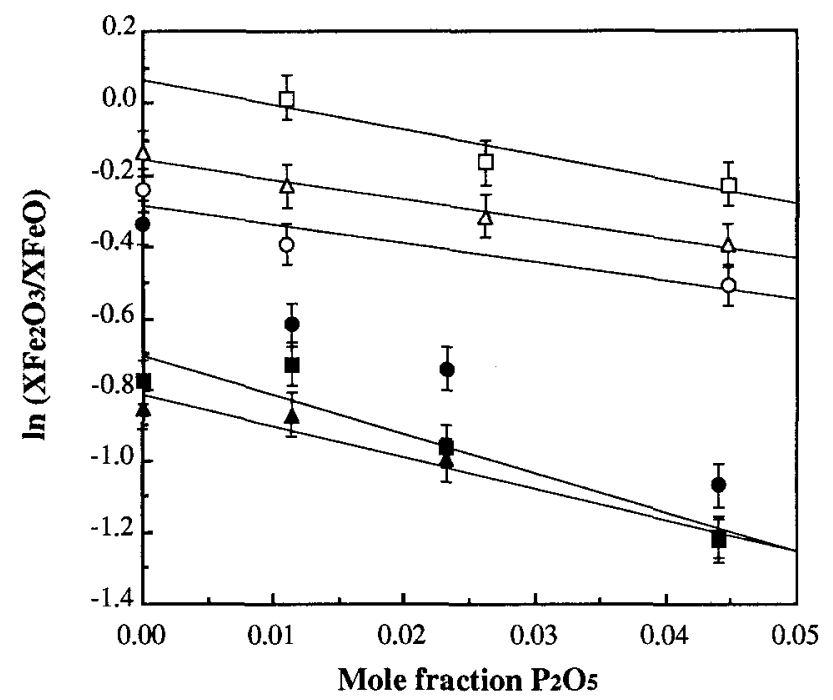

Fig. 1. The iron redox ratio [expressed as $\left.\ln \left(X_{F_{2}} \mathrm{O}_{3} / X \mathrm{FeO}\right)\right]$ as a function of the mole fraction of $\mathrm{P}_{2} \mathrm{O}_{5}$ added. Filled symbols represent experiments carried out in a $\mathrm{CO}_{2}$ atmosphere (squares $1400^{\circ} \mathrm{C}$, triangles $1500^{\circ} \mathrm{C}$, circles $1600^{\circ} \mathrm{C}$ ), and the open symbols represent experiments carried out in air (squares $1397^{\circ} \mathrm{C}$, triangles $1446^{\circ} \mathrm{C}$, circles $1545^{\circ} \mathrm{C}$ ). A linear regression of each data set is also shown (the fit to the data $r^{2}$ varies between 0.87 and 0.98 ). The gradient varies from 5.4 to 6.9 in air, and from 8.8 to 10.9 in $\mathrm{CO}_{2}$. Experiments in $\mathrm{CO}_{2}$ at $1600^{\circ} \mathrm{C}$ are not considered due to potential oxidation (as discussed in the text)

of these compositions over the studied temperature range. This contrasts with the viscosity of pure molten $\mathrm{P}_{2} \mathrm{O}_{5}$, which shows Arrhenian behaviour over a large temperature range (Cormia et al. 1963). For each composition the data have been regressed using an equation of the form:

$\log _{10} \eta(\mathrm{dPa} s)=a+b / T$

The $a$ and $b$ parameters and calculated values of the activation energy $E$ using Eq. (1) are shown in Table 4.

The effect of the addition of $\mathrm{P}_{2} \mathrm{O}_{5}$ on viscosity is shown in Figs. 3a-c along three isotherms covering the studied range of temperature. At low $\mathbf{P}$ contents in air there is an initial decrease in viscosity at all the studied temperatures. In a $\mathrm{CO}_{2}$ atmosphere at $1600^{\circ} \mathrm{C}$ a decrease in viscosity at low $\mathrm{P}$ content is also observed, while at 1400 and $1250^{\circ} \mathrm{C}$ the viscosity shows a small initial increase. Further addition of phosphorus leads to a large increase in the viscosity of the melt in both air and $\mathrm{CO}_{2}$. The viscosity of a fixed composition measured in $\mathrm{CO}_{2}$ is always lower than that measured in air. The magnitude of this decrease is greatest in phosphorus-free melts (typically $10 \%$ relative) and decreases to almost zero for the composition containing $9.5 \mathrm{wt} \% \mathrm{P}_{2} \mathrm{O}_{5}$ (Figs. $3 \mathrm{a}-\mathrm{c}$ ). This range of variation in viscosity due to changing oxidation state is consistent with that observed for various ferro-silicate compositions (Dingwell and Virgo 1987; Dingwell 1991).

When considering the variation of viscosity due to the addition of phosphorus, the reduction of ferric to ferrous iron must also be taken into account. The viscosity of the Fe-bearing silicate melts studied by Dingwell (1991) all showed the same general dependence on oxidation state. At oxidizing conditions $\left(\mathrm{Fe}^{2+} / \Sigma \mathrm{Fe}<0.3\right)$ the reduction of ferric to ferrous iron causes a large decrease in viscosity. However, with further reduction, the viscosity decrease (i.e $\Delta \eta / \Delta \mathrm{Fe}^{2+} / \Sigma \mathrm{Fe}$ ) diminishes to zero, and the viscosity reaches a steady value, independent of the ferric-ferrous ratio. At fixed temperature and $f_{\mathrm{O}_{2}}$, the variation of viscosity on addition of $\mathrm{P}_{2} \mathrm{O}_{5}$ is therefore considered to be controlled by: (1) a reduction of ferric iron which favours a decrease in viscosity; (2) a change in melt structure which favours an increase in viscosity. With decreasing ferric iron content, process (2) becomes progressively dominant, and the increase in viscosity, with addition of phosphorus, will approach linearity. Under these conditions, the viscosity may be approximated by an equation of the form:

$\log _{10} \eta(\mathrm{dPa} s)=\Sigma X_{i} D_{i}$

where $\eta$ is the viscosity, $X_{i}$ is the mole fraction of the oxide component $i$ and $D_{i}$ is an empirical constant associated with component $i$ for a given temperature. The gradient of the linear portion of Figs. $3 \mathrm{a}-\mathrm{c}$ thus allows us to estimate values for $\mathrm{D}_{\mathrm{P}_{2} \mathrm{O}_{5}}$ (the viscosity coefficient of phosphorus, in the sense of Bottinga and Weill 1972) in this melt at various temperatures. Values for the viscosity coefficient at $50^{\circ} \mathrm{C}$ intervals between 1600 and $1250^{\circ} \mathrm{C}$ are shown in Table 5 .

The effect of $\mathrm{P}_{2} \mathrm{O}_{5}$ on density

The densities of the studied compositions are shown graphically in Fig. 4a as a function of the weight percent $\mathrm{P}_{2} \mathrm{O}_{5}$ added. The measured values of density, the calculated molar mass (using the measured values of ferric and ferrous iron), and the calculated molar volumes ( = molar mass/density) of these compositions are shown in Table 6. Figure $4 \mathrm{~b}$ shows the calculated molar volume as a function of the mole percent $\mathrm{P}_{2} \mathrm{O}_{5}$ in the liquid. The data show that addition of phosphorus causes a significant decrease in the density of the ferrobasaltic starting composition (Fig. 4a). The rate of decrease of density and increase of the molar volume are linear within the error of the experimental measurements. If the partial molar volume $\left(V_{m}\right)$ of the SC4 component (i.e. the $\mathrm{P}_{2} \mathrm{O}_{5}$-free fraction of the melt) remains constant then the molar volume of the system is described by:

$V_{m}=(1-x) V_{m}^{V \mathrm{SC} 4}+x V_{m}^{\mathrm{P}_{2} \mathrm{O}_{5}}$

where $x$ is the mole fraction of $\mathrm{P}_{2} \mathrm{O}_{5}$. Rearranging Eq. (4) gives $V_{m}$ as a function of $x$ and the $y$-intercept is 
Table 3 Viscosity measurements

\begin{tabular}{|c|c|c|c|c|c|c|c|}
\hline $\begin{array}{l}\text { Air } \\
\text { Run no. }\end{array}$ & $\begin{array}{l}\mathrm{P}_{2} \mathrm{O}_{5}(\mathrm{wt} \%) \\
(\mathrm{mol} \%)\end{array}$ & $T^{\circ} \mathrm{C}$ & $\begin{array}{l}\log _{10} \text { viscosity } \\
(\mathrm{dPa})\end{array}$ & $\begin{array}{l}\mathrm{CO}_{2} \\
\text { Run no. }\end{array}$ & $\begin{array}{l}\mathrm{P}_{2} \mathrm{O}_{5}(\mathrm{wt} \%) \\
(\mathrm{mol} \%)\end{array}$ & $T^{\circ} \mathrm{C}$ & $\begin{array}{l}\log _{10} \text { viscosity } \\
(\mathrm{dPa} \mathrm{s})\end{array}$ \\
\hline MTV4 & $\begin{array}{l}2.40 \\
1.11\end{array}$ & $\begin{array}{l}1594 \\
1545 \\
1496 \\
1446 \\
1397\end{array}$ & $\begin{array}{l}0.946 \\
1.088 \\
1.238 \\
1.399 \\
1.565\end{array}$ & MTV9 & $\begin{array}{l}2.51 \\
1.14\end{array}$ & $\begin{array}{l}1600 \\
1550 \\
1500 \\
1450 \\
1400 \\
1350 \\
1300 \\
1250\end{array}$ & $\begin{array}{l}0.936 \\
1.075 \\
1.225 \\
1.388 \\
1.551 \\
1.733 \\
1.938 \\
2.173\end{array}$ \\
\hline MTV3 & $\begin{array}{l}5.62 \\
2.63\end{array}$ & $\begin{array}{l}1594 \\
1545 \\
1496 \\
1446 \\
1397 \\
1348 \\
1299 \\
1249\end{array}$ & $\begin{array}{l}1.051 \\
1.185 \\
1.337 \\
1.498 \\
1.672 \\
1.851 \\
2.072 \\
2.316\end{array}$ & . & $\begin{array}{l}4.92 \\
2.32\end{array}$ & $\begin{array}{l}1600 \\
1550 \\
1500 \\
1450 \\
1400 \\
1350 \\
1300 \\
1250\end{array}$ & $\begin{array}{l}0.995 \\
1.128 \\
1.283 \\
1.446 \\
1.623 \\
1.809 \\
2.027 \\
2.275\end{array}$ \\
\hline MTV1 & $\begin{array}{l}9.54 \\
4.47\end{array}$ & $\begin{array}{l}1594 \\
1570 \\
1545 \\
1496 \\
1446 \\
1397 \\
1348 \\
1299 \\
1249 \\
1200\end{array}$ & $\begin{array}{l}1.135 \\
1.194 \\
1.267 \\
1.427 \\
1.589 \\
1.761 \\
1.966 \\
2.199 \\
2.446 \\
2.760\end{array}$ & MTV8 & $\begin{array}{l}9.45 \\
4.41\end{array}$ & $\begin{array}{l}1600 \\
1550 \\
1500 \\
1450 \\
1400 \\
1350 \\
1300 \\
1250\end{array}$ & $\begin{array}{l}1.101 \\
1.248 \\
1.412 \\
1.571 \\
1.749 \\
1.956 \\
2.188 \\
2.457\end{array}$ \\
\hline
\end{tabular}

$V_{m}^{\mathrm{SC} 4}$. This gives a calculated $V_{m}^{\mathrm{P}_{2} \mathrm{O}_{5}}$ of $59.7 \mathrm{~cm}^{3} / \mathrm{mol}$ for $\mathrm{P}_{2} \mathrm{O}_{5}$ at $1292^{\circ} \mathrm{C}$ in this melt. However, because there is a change of ferric-ferrous ratio associated with the addition of phosphorus, the molar volume of the SC4 component does not remain constant. The magnitude of this effect has been evaluated by calculating the $V_{m}^{\mathrm{SC} 4}$ for the normalized P-free portion of each melt, using the major element data from Table 1 , the ferric-ferrous determinations from Table 2 , and the calculation procedure of Lange and Carmichael (1990). These values are shown in Table 6 and plotted in Fig 4b. This effect leads to a decrease of $V_{m}^{\mathrm{sC} 4}$ which is small compared to the increase due to the addition of $\mathrm{P}_{2} \mathrm{O}_{5}$ but must be corrected for in the calculation of $V_{m}^{\mathrm{P}_{2} \mathrm{O}_{5}}$. This gives a revised value for the partial molar volume of $\mathrm{P}_{2} \mathrm{O}_{5}$ in this melt at $1292^{\circ} \mathrm{C}$ of $64.5 \pm 0.7 \mathrm{~cm}^{3} / \mathrm{mol}$. This partial molar volume is $12.9 \mathrm{~cm}^{3} / \mathrm{mol}$ per oxygen, consistent with a tetrahedral coordination for this high field strength cation (Lange and Carmichael 1990).

\section{Discussion}

Estimation of the physical properties of $\mathrm{P}_{2} \mathrm{O}_{5}$-bearing melts using existing calculation schemes

A knowledge of the physical properties of magmas is essential for a complete understanding of magmatic processes and interpretation of field observations, thus calculation schemes for estimating their values have become invaluable aids to petrologists. Despite the minor element concentrations of $\mathrm{P}_{2} \mathrm{O}_{5}$ in most natural compositions, it does not appear in the commonly used schemes for the calculation of ferric-ferrous ratio (Kilinc et al. 1983) or density (Lange and Carmichael 1990) and is simply added to silicon in the scheme of Bottinga and Weill (1972) for viscosity. Below we assess the success of the above models to predict these parameters in phosphorus-bearing systems.

Although the ferric-ferrous ratio of a magma is 


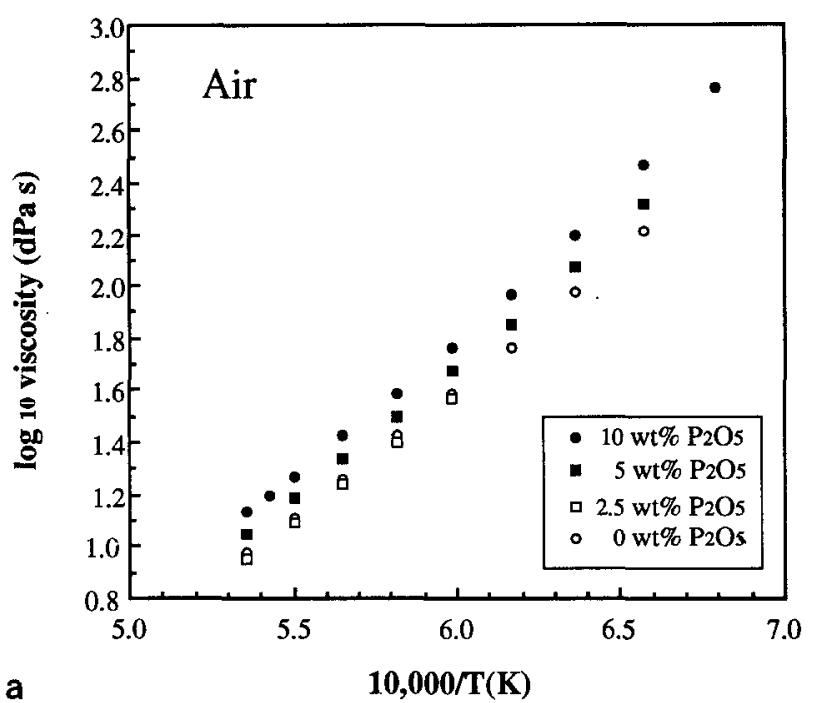

a

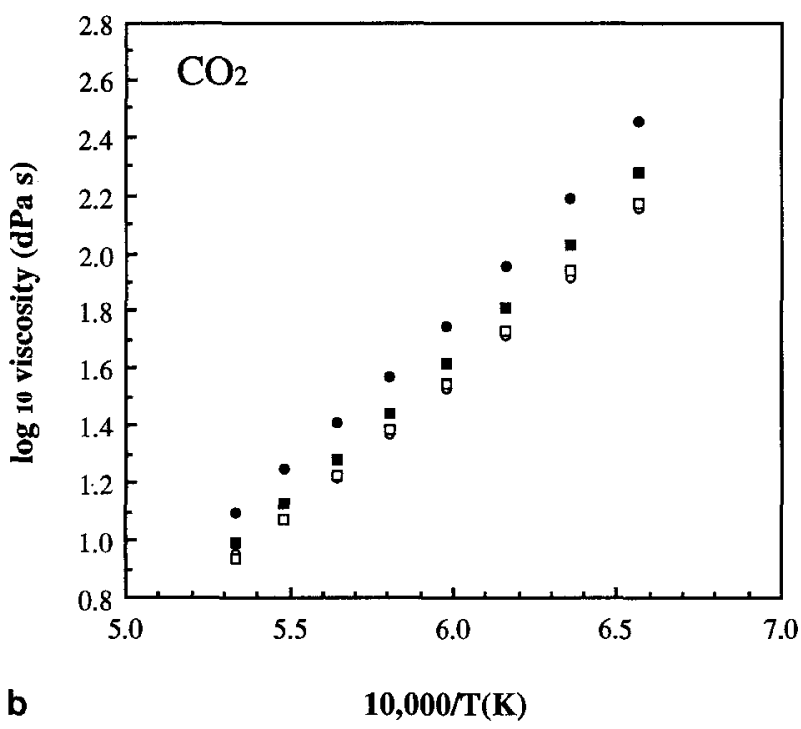

Fig. 2a, b The viscosity-temperature relationship of ferro-basaltic melts with added $\mathrm{P}_{2} \mathrm{O}_{5}$ in (a) air; (b) $\mathrm{CO}_{2}$. (Open circles P-free composition, $\mathrm{SC} 4$, open squares $\mathrm{SC} 4+2.5 \mathrm{wt} \% \mathrm{P}_{2} \mathrm{O}_{5}$, filled squares $\mathrm{SC} 4+5 \mathrm{wt} \% \mathrm{P}_{2} \mathrm{O}_{5}$, filled circles $\left.\mathrm{SC} 4+10 \mathrm{wt} \% \mathrm{P}_{2} \mathrm{O}_{5}\right)$. See Table 1 for the exact compositions

primarily controlled by temperature and oxygen fugacity, there is also an important compositional dependence (Fudali 1965; Thornber et al. 1980; Sack et al. 1980; Kilinc et al. 1983). The most successful method to date for the estimation of ferric-ferrous ratios, first used by Sack et al. (1980), uses an empirical equation of the form below:

$\ln \left(X \mathrm{Fe}_{2} \mathrm{O}_{3} / X \mathrm{FeO}\right)=a \ln f_{\mathrm{O}_{2}}+b / T+c+\Sigma d_{i} X_{i}$

where $T$ is the absolute temperature, $X_{i}$ is the mole fraction of the species $i$, and $a, b, c, d_{i}$ are constants calculated from a linear regression of experimentally determined ferric-ferrous ratios over a wide range of composition, temperature and $f_{\mathrm{O}_{2}}$. The commonly used regression of Kilinc et al. (1983) contains compositional
Table 4 Fit parameters and calculated activation energies for the studied melts assuming Arrhenian behaviour

\begin{tabular}{llllr}
\hline Run no. & $\mathrm{a}$ & $\mathrm{b}\left(\times 10^{4}\right)$ & $\mathrm{E}\left(\mathrm{kJ} \mathrm{mol}^{-1}\right)$ & $n$ \\
\hline MTV2 $^{-1}$ & $-4.46^{\mathrm{b}}$ & $1.012^{\mathrm{a}}$ & 193.8 & 8 \\
MTV4 $^{\mathrm{a}}$ & -4.30 & 0.980 & 187.7 & 5 \\
MTV3 & -4.51 & 1.036 & 198.4 & 8 \\
MTV1 & -4.91 & 1.121 & 214.6 & 10 \\
MTV6 & -4.28 & 0.975 & 186.7 & 8 \\
MTV9 & -4.41 & 1.000 & 191.4 & 8 \\
MTV7 & -4.57 & 1.038 & 198.7 & 8 \\
MTV8 & -4.75 & 1.093 & 209.2 & 8 \\
\hline
\end{tabular}

${ }^{a} \mathrm{NB}$ only five data points

${ }^{b}$ The fit $r^{2}$ is $>0.995$ in all cases ( $n$ number of data points used in the regression)

terms only for $K_{2} \mathrm{O}\left(\mathrm{d}_{\mathrm{K}_{2} \mathrm{O}},+9.6\right) ; \mathrm{Na}_{2} \mathrm{O}\left(\mathrm{d}_{\mathrm{Na}_{2} \mathrm{O}},+8.4\right)$; $\mathrm{CaO}\left(\mathrm{d}_{\mathrm{CaO}},+3.0\right)$; total iron as $\mathrm{FeO}\left(\mathrm{FeO}^{*}\right)$ $\left(\mathrm{d}_{\mathrm{FeO}},+1.6\right) ; \mathrm{Al}_{2} \mathrm{O}_{3}\left(\mathrm{~d}_{\mathrm{Al}_{2} \mathrm{O}_{3}},-2.2\right)$. The gradient of Fig. 1 suggests that $\mathrm{d}_{\mathrm{P}_{2} \mathrm{O} 5}$ has a value of at least-6, implying that $\mathrm{P}_{2} \mathrm{O}_{5}$ has a greater reducing effect than any of the quoted oxide components. Furthermore, Fig. 1 suggests even greater absolute values of $\mathrm{d}_{\mathrm{P}_{2} \mathrm{O}_{5}}$ at lower $f_{\mathrm{O}_{2}}$. The success of the formulation of Kilinc et al. (1983) in estimating the ferric-ferrous ratio of these melts is shown in Fig. 5. The data lie within an acceptable range given the relatively large uncertainties ( $\pm 0.2 \ln$ units) associated with the model. In general, low phosphorus glasses (open symbols) lie below the 1:1 correlation, while high phosphorus glasses (filled symbols) lie above it, in agreement with the observed reducing effect of phosphorus. In the light of the potential problems of oxidation during the quench discussed earlier, the measured values will tend to overestimate the ferric-ferrous ratio, particularly at high temperature. If the values measured at high temperature are qualitatively shifted to lower ferric-ferrous ratios, the phosphorus-rich compositions will then lie well above the $1: 1$ correlation, i.e. the model of Kilinc et al. (1983) will underestimate the ferric-ferrous ratio. For a large range of basaltic melts the formulations of Kilinc et al. (1983) remains the best possible means of calculating ferric-ferrous ratios. However, in the light of these results, we suggest that for phosphorus-bearing basaltic melts, a compositional term for $\mathrm{P}_{2} \mathrm{O}_{5}$ of at least-6 should be used.

In order to estimate the viscosity of natural melts, Bottinga and Weill (1972) used a large set of viscosity measurements to evaluate viscosity coefficients for many melt components (using the form of Eq. 3), at $50^{\circ} \mathrm{C}$ and restricted $\mathrm{SiO}_{2}$ mole fraction intervals. There is no phosphorus-bearing component in this model, although the authors suggest that phosphorus should be added to silicon. Our experimental results and the calculated viscosities using the model of Bottinga and Weill (Fig. 6) are in good agreement, and well within the errors stated for the model $\left( \pm 0.2 \log _{10}\right.$ units). The 

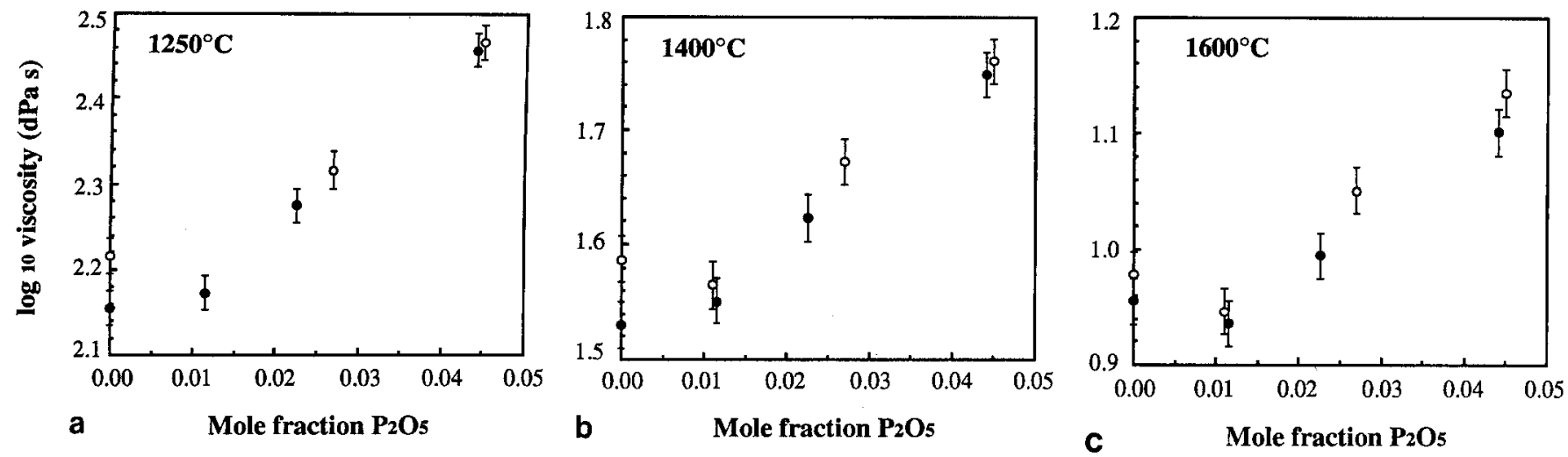

Fig. 3a-c The viscosity as a function of mole fraction $\mathrm{P}_{2} \mathrm{O}_{5}$ added at (a) $1250^{\circ} \mathrm{C}$; (b) $1400^{\circ} \mathrm{C}$; (c) $1600^{\circ} \mathrm{C}$. The exact temperatures are marked in Table 3. (Filled symbols experiments carried out in $\mathrm{CO}_{2}$, open symbols experiments carried out in air

Table 5 Viscosity coefficients for $\mathrm{P}_{2} \mathrm{O}_{5}$

\begin{tabular}{llll}
\hline$T^{\circ} \mathrm{C}$ & $\begin{array}{l}\mathrm{D}_{\mathrm{P}_{2} \mathrm{O}_{5}} \\
\log _{10} \mathrm{dpa} \mathrm{mol}\end{array}$ & $\begin{array}{l}\mathrm{D}_{\mathrm{PO}_{2.5}} \\
\ln \mathrm{dpa} \mathrm{mol} \mathrm{mol}^{-1}\end{array}$ & $\begin{array}{l}\mathrm{D}_{\mathrm{SiO}_{2}}(\mathrm{~B}+\mathrm{W} \mathrm{72})^{\mathrm{a}} \\
\operatorname{ln~dpa~mol}\end{array}$ \\
\hline 1600 & 5.06 & 5.83 & $4.87^{\mathrm{b}}-6.80^{\mathrm{c}}$ \\
1550 & 5.36 & 6.17 & $5.39-7.35$ \\
1500 & 5.79 & 6.67 & $6.00-7.97$ \\
1450 & 5.66 & 6.52 & $6.60-8.58$ \\
1400 & 6.06 & 6.98 & $7.26-9.25$ \\
1350 & 6.86 & 7.90 & $7.97-9.97$ \\
1300 & 7.66 & 8.82 & $8.70-10.72$ \\
1250 & 8.70 & 10.02 & $9.50-11.52$ \\
\hline
\end{tabular}

${ }^{a}$ Values quoted by Bottinga and Weill (1972)

b For $X \mathrm{SiO}_{2}=0.45-0.55$

${ }^{\mathrm{c}}$ For $X \mathrm{SiO}_{2}=0.55-0.65$

addition of phosphorus to silicon thus seems to be appropriate. This may be understood in terms of the similarity of the calculated viscosity coefficients for $\mathrm{PO}_{2.5}$ and $\mathrm{SiO}_{2}$ at the same temperature (Table 5). Thus the addition of phosphorus to ferro-basaltic melts increases the viscosity in an almost identical manner to that of $\mathrm{SiO}_{2}$.

The partial molar volume data presented by Lange and Carmichael (1990) represent the most recent method of estimating the densities of natural magmas. The quoted values for partial molar volume are assumed to be compositionally independent although there are data indicating that the partial molar volumes of $\mathrm{Fe}_{2} \mathrm{O}_{3}$ and $\mathrm{TiO}_{2}$ exhibit compositional dependence (for $\mathrm{Fe}_{2} \mathrm{O}_{3}$ see Dingwell and Brearley 1988; Hara et al. 1988; Dingwell 1990; for $\mathrm{TiO}_{2}$ see Johnson and Car michael 1987; Dingwell 1992 also see review by Lange and Carmichael 1990) and the case of $\mathrm{Al}_{2} \mathrm{O}_{3}$ remains unclear (Ghiorso and Carmichael 1984; Bottinga et al. 1982, 1984). The values of density obtained here, even in the phosphorus-free system, show considerable discrepancy with the values calculated using the scheme of Lange and Carmichael (1990). This may result from the
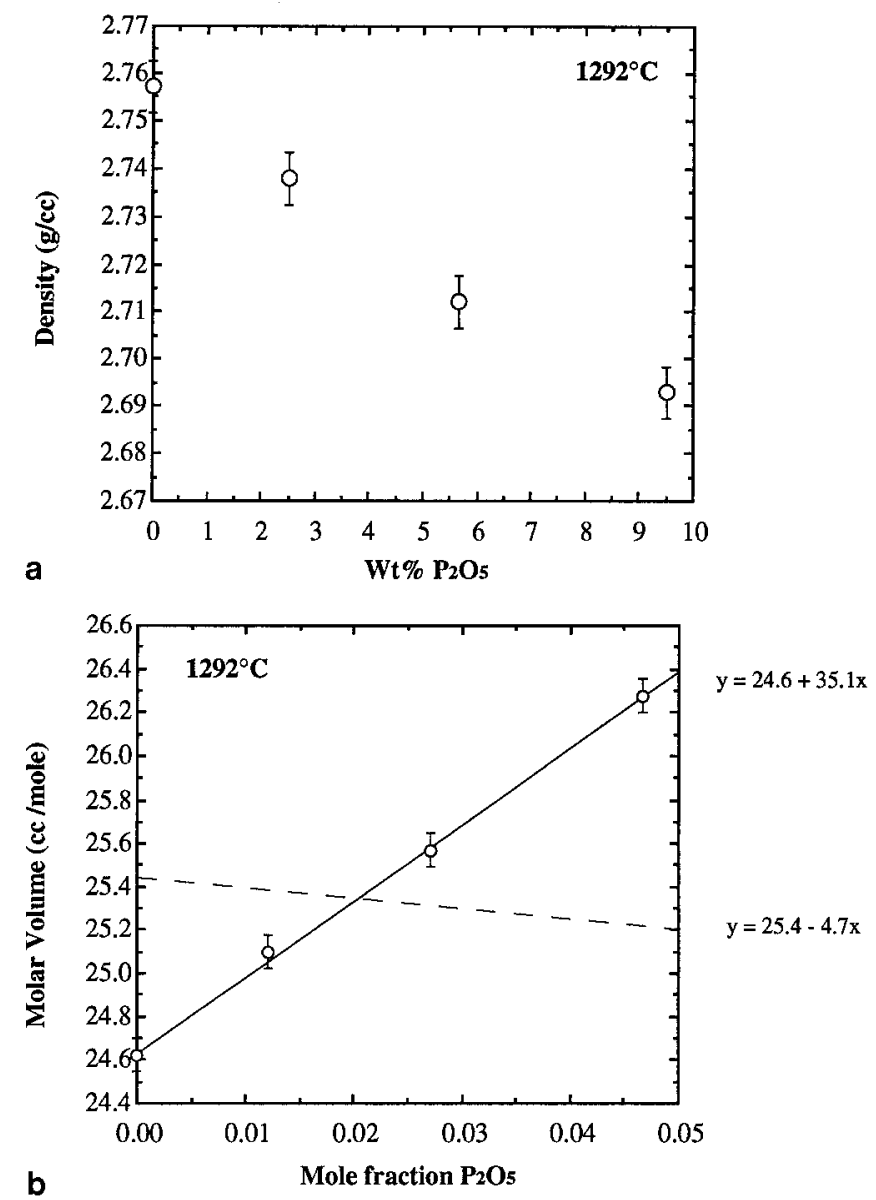

Fig. 4a The measured density of the studied melts as a function of the weight percent $\mathrm{P}_{2} \mathrm{O}_{5}$ in the liquid. The error bars represent the error of measurement, $0.2 \%$. b The molar volumes of the studied melts (estimated from the measured densities) as a function of the mole fraction of $\mathrm{P}_{2} \mathrm{O}_{5}$ added. The change in the molar volume of the $P$-free fraction, due to changing ferric-ferrous ratio, estimated from the data of Lange and Carmichael (1990), is also shown (dashed line)

ferric iron- and titanium-rich nature of the studied composition. Figure $4 \mathrm{~b}$ shows the important increase in partial molar volume associated with the addition of phosphorus to this composition. Therefore, the calculated partial molar volume of $64.5 \mathrm{~cm}^{3} / \mathrm{mol}$ at $1300^{\circ} \mathrm{C}$ for $\mathrm{P}_{2} \mathrm{O}_{5}$ should be included in the calculation of basaltic liquid densities. 
Table 6 Density determinations

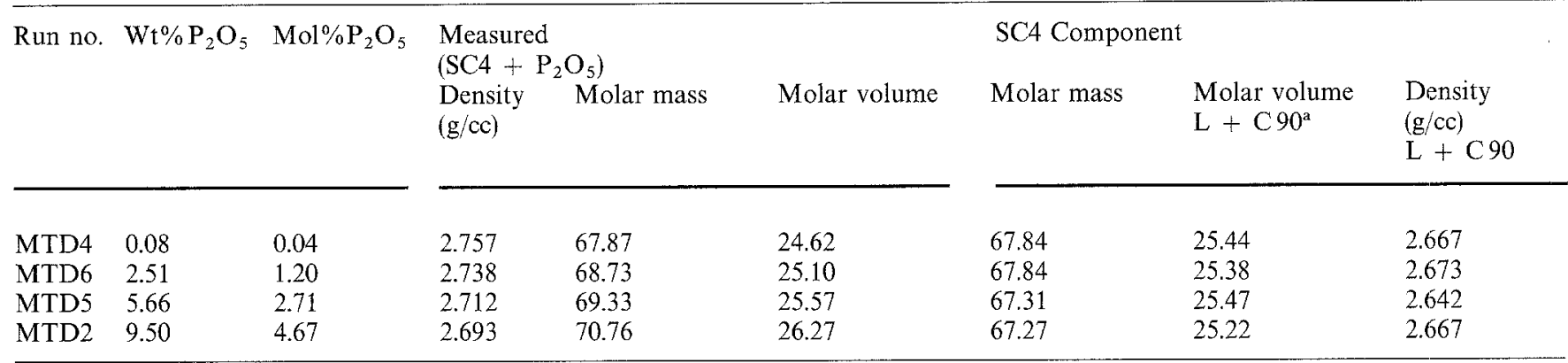

${ }^{a}$ Calculated from the normalized P-free compositions (Table 1), the measured ferric and ferrous iron contents (Table 2), and the oxide partial molar volumes of Lange and Carmichael (1990)

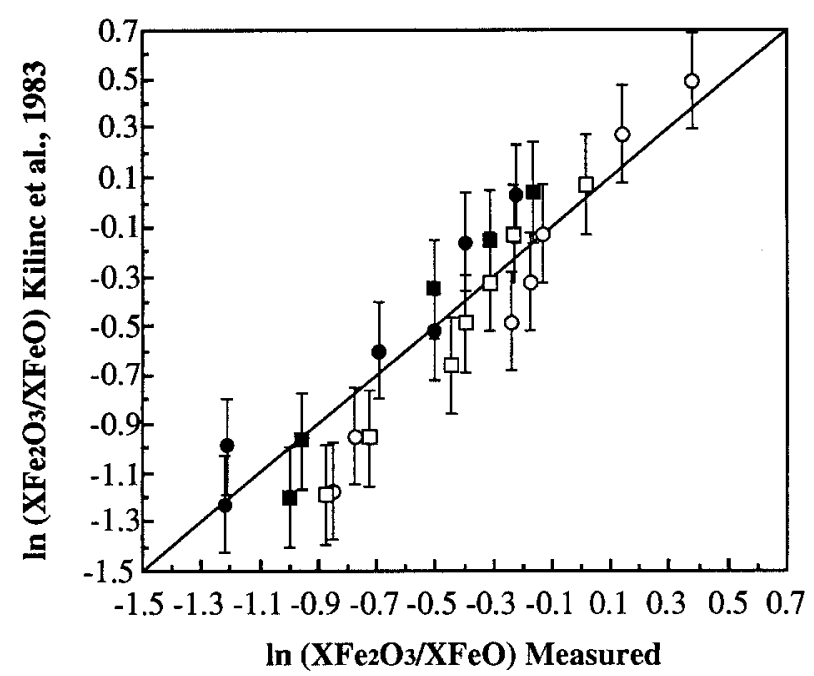

Fig. 5 Measured values of the iron redox ratio [expressed as in $\left.\left(X \mathrm{Fe}_{2} \mathrm{O}_{3} / X \mathrm{FeO}\right)\right]$ compared with values calculated using the scheme of Kilinc et al. (1983). Symbols are the same as Fig. 2. Samples taken above $1570^{\circ} \mathrm{C}$ are not shown due to potential oxidation (as discussed in the text)

Implications for the structural role of $\mathrm{P}$ in ferro-basaltic melts

The solution behaviour of phosphorus in silicate melts is complex. The addition of $\mathrm{P}_{2} \mathrm{O}_{5}$ to pure $\mathrm{SiO}_{2}$ lowers the liquidus temperatures of silica polymorphs, indicating a decrease of the silica activity $\left(a_{\mathrm{SiO}_{2}}\right)$, caused by depolymerization via the formation of $\mathrm{P}-\mathrm{O}-\mathrm{Si}$ bonds in the silicate network (Ryerson and Hess 1980). In contrast, spectroscopic (Nelson and Tallant 1984; Duprée et al. 1988; Mysen 1992; Gan and Hess 1992) and phase equilibria (Kushiro 1975; Ryerson and Hess 1980; Ryerson 1985) evidence from melts rich in network modifying metal cations suggests that addition of phosphorus removes these metal cations to form discrete phosphate $\left(\mathrm{PO}_{4}^{3-}\right)$ complexes outside of the aluminosilicate network where $\mathbf{P}$ is tetrahedrally coordinated (consistent with the calculated partial molar volume per oxygen of phosphorus in this melt). This results in the formation of more $\mathrm{Si}-\mathrm{O}-\mathrm{Si}$ bonds, by

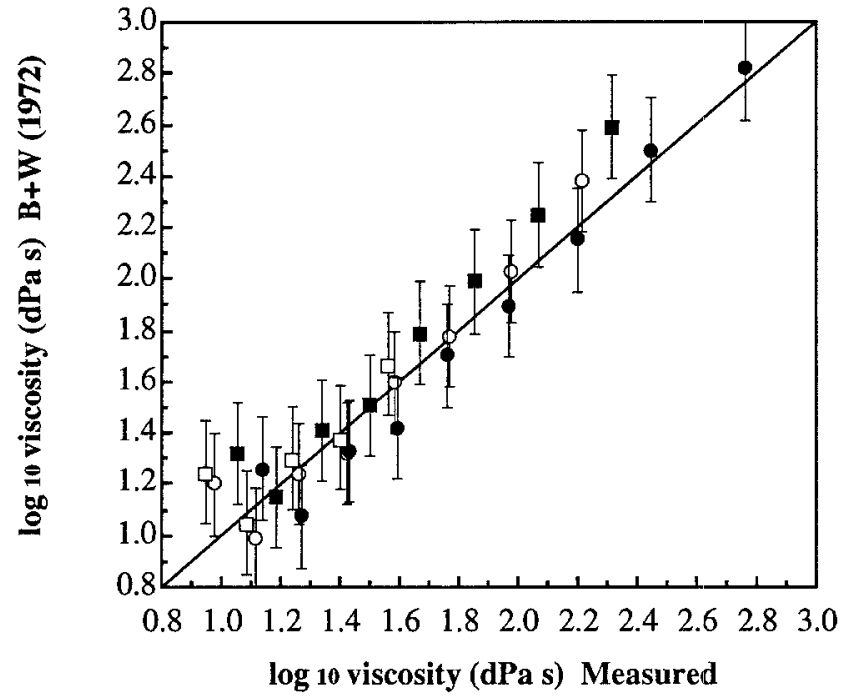

Fig. 6 Comparison of measured values of the melt viscosity for experiments carried out in air, with values calculated using the scheme of Bottinga and Weill (19782). Symbols as in Fig. 2

a reaction of the type:

$2 \mathrm{Si}-\mathrm{O}-\mathrm{M}+\mathrm{P}-\mathrm{O}-\mathrm{P} \Leftrightarrow \mathrm{Si}-\mathrm{O}-\mathrm{Si}+2 \mathrm{P}-\mathrm{O}-\mathrm{M}$

where $M$ is a metal cation. The increase in polymerization of the aluminosilicate network associated with reaction (6) may be expected to cause an increase in viscosity, because silicate melts rich in network forming cations are generally more viscous than those rich in network modifying cations. The overall increase in viscosity with the addition of $\mathrm{P}_{2} \mathrm{O}_{5}$ observed for this melt (Fig. 3) is a rare exception to the rule that the dilution of $\mathrm{SiO}_{2}$ and $\mathrm{Al}_{2} \mathrm{O}_{3}$ in basic melts reduces the viscosity, and supports the evidence that reaction (6) is a plausible mechanism to describe the solution behaviour of phosphorus in these melts. However, if reaction (6) alone was controlling the variation of viscosity as $\mathrm{P}_{2} \mathrm{O}_{5}$ is added, one would expect the $\eta$ versus $X \mathrm{P}_{2} \mathrm{O}_{5}$ curves (Fig. 3) to be linear, which at low $\mathrm{P}_{2} \mathrm{O}_{5}$ contents they are not. As stated previously, we attribute the 
variation in viscosity at low $\mathrm{P}_{2} \mathrm{O}_{5}$ content to the observed reduction of ferric to ferrous iron. Under oxidizing conditions, ferric iron is known to be, at least in part, tetrahedrally coordinated in silicate melts (Mysen et al. 1980, 1985; Dingwell and Virgo 1987). The destabilization of tetrahedral (network forming) ferric iron will result in the formation of ferrous iron and the release of the charge balancing cations associated with the $\mathrm{Fe}^{3} \leftrightarrow \mathrm{Si}^{4+}$ substitution. These cations are most likely to occupy network modifying roles, thus decreasing the bulk polymerization and favouring a decrease of viscosity. With the addition of phosphorus, the overall viscosity change will therefore be a function of the increasing polymerization associated with reaction (6) and the decreasing polymerization due to the destabilization of tetrahedral ferric iron. The observed form of the $\eta$ versus $X \mathrm{P}_{2} \mathrm{O}_{5}$ curves suggests that at low $\mathrm{P}$ content, the reduction of ferric iron has an influence on the viscosity which is of the same order of magnitude as that caused by the polymerizing effect of $\mathrm{P}_{2} \mathrm{O}_{5}$. In air, where ferric iron contents are greatest, this effect may cause a decrease in viscosity, while in a $\mathrm{CO}_{2}$ atmosphere, where ferric iron contents are lower, reaction (6) just dominates. The subsequent strong increase of viscosity with further addition of $\mathrm{P}_{2} \mathrm{O}_{5}$ implies that reaction (6) has an increasing influence on the overall viscosity change, despite the fact that ferric iron is still being reduced. This is consistent with the viscosity data of Dingwell (1991), where the viscosity decrease due to the reduction of ferric iron is strong at oxidizing conditions, but diminishes to zero with increasing reduction. This may be explained by ferric iron becoming increasingly in octahedral rather than tetrahedral coordination as the oxidation state falls, as has been suggestedfrom Mössbauer spectra of various iron-bearing melts (Mysen et al. 1985).

Indications of the structural role of phosphorus in this basaltic melt may also be inferred from the rate of increase of viscosity at high $\mathrm{P}$ content (i.e $\mathrm{D}_{\mathrm{P}_{2} \mathrm{O}_{5}}$ ). The fact that $\mathrm{D}_{\mathrm{PO} 2.5}$ and $\mathrm{D}_{\mathrm{SiO}_{2}}$ have similar values (Table 5), implies that the equimolar addition of $\mathrm{PO}_{2.5}$ and $\mathrm{SiO}_{2}$ results in a comparable increase in viscosity. This is entirely consistent with Eq. (6), where the addition of phosphorus (P-O-P) results in the formation of
$\mathrm{Si}-\mathrm{O}-\mathrm{Si}$ bonds. The increase in viscosity associated with the addition of phosphorus may be viewed thermodynamically as a combination of an increase in mean cation oxygen bond strength due to the increased number of $\mathrm{Si}-\mathrm{O}-\mathrm{Si}$ bonds (enthalpic effect), as well as a contribution from increased ordering in the liquid structure due to the non-participation of $\mathrm{P}$ in the silicate network (entropic effect).

The studied ferro-basaltic composition is rich in network modifying cations, and reaction (6) may proceed to the right for the entire range of studied $\mathrm{P}_{2} \mathrm{O}_{5}$ content. A comparison of our results with those obtained in a granitic system, where insufficient cations are available to allow reaction (6) take place, (Dingwell et al. 1992, 1993; Gwinn and Hess 1993) are summarized in Table 7 . The observed variations and effects of phosphorus on the viscosity, density and ferricferrous ratio of this ferro-basalt all contrast with the results obtained in the granitic system. This provides further evidence that the speciation of phosphorus is very different in silica-rich and silica-poor melts (e.g. Mysen 1988). Such a large dependence of the effects of phosphorus on bulk composition highlights the danger of extrapolation of results outside of the compositional range where they were collected.

\section{Implications for natural systems}

A number of natural ferro-basaltic systems, with compositions similar to those studied here have been reported to have important enrichments in $\mathrm{P}_{2} \mathrm{O}_{5}$. The Skaergaard Intrusion is an example where the coexisting liquid has been estimated to have contained a maximum of $1.3-1.75 \mathrm{wt} \% \mathrm{P}_{2} \mathrm{O}_{5}$ (Wager and Brown 1967; McBirney and Naslund 1990). This range of values may be typical of layered basic intrusions where phosphorus enriches in the melt until the crystallization of a phosphate phase. Monzonoritic compositions found in association with many massive anorthosites commonly contain in excess of $2 \mathrm{wt} \% \mathrm{P}_{2} \mathrm{O}_{5}$ (Morse 1982; Duschene 1984), and enrichments of up to $8 \mathrm{wt} \% \mathrm{P}_{2} \mathrm{O}_{5}$ have been documented for some iron-rich immiscible liquid globules (Philpotts 1982).
Table 7 Summary and comparison with granitic system

\begin{tabular}{|c|c|c|}
\hline Property & $\begin{array}{l}\text { Composition } \\
\text { Ferrobasalt }\end{array}$ & Granite \\
\hline Effect on ferric-ferrous ratio & Large decrease & Small increase ${ }^{\mathbf{a}}$ \\
\hline Effect on viscosity & Large increase & Small decrease ${ }^{b}$ \\
\hline Arrhenian behaviour & No & Yes $^{b}$ \\
\hline Activation energy $(\mathrm{kJ} / \mathrm{mol})$ & $187-215$ & $372-436^{b}$ \\
\hline Partial molar volume $(\mathrm{cc} / \mathrm{mol}$ & 64.5 at $1292^{\circ} \mathrm{C}$ & 67.1 at $750^{\circ} \mathrm{C}^{\mathrm{c}}$ \\
\hline
\end{tabular}

${ }^{a}$ From Gwinn and Hess (1993)

${ }^{\mathrm{b}}$ From Dingwell et al. (1993)

c From Dingwell et al. (1992) 
The observed reduction of ferric to ferrous iron in these liquids may affect the stability of $\mathrm{Fe}-\mathrm{Ti}$ oxides at lower temperature. Indeed, Toplis et al. (1994) observed that the addition of phosphorus to this same composition (SC4), resulted in a large destabilization of magnetite. Although this destabilization was attributed to formation of $\mathrm{P}-\mathrm{Fe}^{3+}$ complexes in the melt, the results of this study indicate that the reduction of ferric iron will also play a role. More experiments are needed to clarify the relative roles of these two processes at conditions around the FMQ buffer, relevant to the crystallization of natural basaltic systems (Carmichael 1991).

The viscosity of a magma controls many of the physical processes occurring in crustal magma chambers. This study shows that for melts rich in ferric iron, enrichment in phosphorus of a few weight percent may not greatly affect the viscosity. However, natural basalts have low ferric iron contents, due to the low $f_{\mathrm{O}_{2}}$ prevailing during crystallization. Therefore, the effect of phosphorus will, above all, be to increase the viscosity. This increase is of the order of $15 \%$ relative per wt $\% \mathrm{P}_{2} \mathrm{O}_{5}$ (Fig. 3a) at temperatures relevant to the crystallization of natural basalts $\left(1100-1200^{\circ} \mathrm{C}\right)$. Thus this effect of phosphorus on the viscosity must be taken into account when estimating physical processes, such as flow mechanisms and mass transfer of natural basaltic magmas.

The trend of iron enrichment during tholeiitic differentiation generally leads to an increase in melt density, until the appearance on the liquidus of an $\mathrm{Fe}-\mathrm{Ti}$ oxide (e.g. Snyder et al. 1992). Due to the incompatible nature of phosphorus during the early stages of crystallization, the melt phase will become enriched in both iron and phosphorus. This study shows that the phosphorus enrichment will tend to counteract the increase in density due to the iron enrichment. This implies that as differentiation proceeds, the density of the residual liquids may be considerably lower than that predicted by the calculation scheme of Lange and Carmichael (1990). This in turn may affect conclusions reached concerning the relative buoyancy of liquids and crystals, or interstitial and overlying liquids in a cumulate pile. This underlines the fact that phosphorus must be taken into account in calculations of density in ferrobasaltic systems.

\section{Conclusions}

The effects of $\mathrm{P}_{2} \mathrm{O}_{5}$ on the redox ratio, viscosity and density of a ferro-basaltic melt under oxidizing conditions have been determined experimentally. The addition of $\mathrm{P}_{2} \mathrm{O}_{5}$ causes: (1) a reduction of ferric iron; (2) an initial decrease and subsequent strong increase in viscosity; (3) a decrease of density. The variation of all these parameters is shown to be significant. The magnitude of the reduction of ferric iron is greater than that of all the quoted oxide components in the calculation scheme of Kilinc et al. (1983). The overall increase in viscosity at $1200^{\circ} \mathrm{C}$ is estimated to be of the order of $15 \%$ relative per wt $\% \mathrm{P}_{2} \mathrm{O}_{5}$, which is of the same order of magnitude as $\mathrm{SiO}_{2}$. A partial molar volume for $\mathrm{P}_{2} \mathrm{O}_{5}$ of $64.5 \mathrm{~cm}^{3} / \mathrm{mol}$ has been determined for this ferro-basalt at $1300^{\circ} \mathrm{C}$, consistent with a high field strength cation in tetrahedral coordination.

The non linear variation of viscosity may be explained in terms of the competing effects of: (1) the depolymerizing effect caused by the destabilization of tetrahedral ferric iron; (2) the removal of network modifying cations and the formation of more $\mathrm{Si}-\mathrm{O}-\mathrm{Si}$ bonds caused by the addition of $\mathrm{P}$. Thus the addition of phosphorus to ferro-basaltic melts causes variations in both the mean cation-oxygen bond strength and the degree of ordering in the melt structure, that is enthalpic as well as entropic effects.

This study suggests that enrichment in phosphorus during basaltic differentiation may: (1) contribute to the destabilization of magnetic by reduction of ferric iron; (2) influence flow mechanisms and mass transfer processes by the increase in viscosity; (3) affect the relative buoyancy of liquids and crystals as crystallization proceeds; (4) counteract the density increase associated with iron enrichment. However, comparison of the data in ferro-basaltic and granitic systems illustrates the strong compositional dependence of the effect of phosphorus on physical and chemical properties. Extrapolation of these properties outside of the compositional range where they were collected is therefore not advised.

Acknowledgments This study was carried out during a stay by M.J.T. at the Bayerisches Geoinstitut (Bayreuth, Germany). Detlef Krausse and Hubert Schulze are thanked for technical assistance. L. Marin carried out the wet chemical analyses at the CRPG (Nancy, France), and is also thanked. P. Hess, and an anonymous reviewer are acknowledged for their useful comments on an earlier version of this manuscript.

\section{References}

Anderson AT, Greenland LP (1969) Phosphorus fractionation diagram as a quantitative indicator of crystallization differentiation of basaltic liquids. Geochim Cosmochim Acta 33:493-505

Beswick AE, Carmichael ISE (1978) Constraints on mantle source compositions imposed by phosphorus and the rare-earth elements. Contrib Mineral Petrol 67:317-330

Bottinga Y, Weill DF (1972) The viscosity of magmatic liquids: a model for calculation. Am J Sci 272:438-475

Bottinga Y, Weill DF, Richet P (1982) Density calculations for silicate liquids. I. Revised method for aluminosilicate compositions. Geochim Cosmochim Acta 46:909-919

Bottinga Y, Weill DF, Richet P (1984) Density calculations for silicate liquids. Reply to a critical comment by Ghiorso and Carmichael. Geochim Cosmochim Acta 48:409-414

Brooks CK, Nielsen TFD (1978) Early stages in the differentiation of the Skaergaard magma as revealed by a closely related suite of dike rocks. Lithos 11:1-14

Carmichael ISE (1991) The redox states of basic and silicic magmas: a reflection of their source region? Contrib Mineral Petrol 106:129-141

Cormia RL, MacKenzie JD, Turnbull D (1963) Viscous flow and melt allotropy of phosphorus pentoxide. J App Phys 34:2245-2248 
Dingwell DB (1989) Shear viscosities of ferrosilicate liquids. Am Mineral 74:1038-1044

Dingwell DB (1990) Experimental determination of some physical properties of iron bearing silicate liquids. Glastech Ber 63K:289-297

Dingwell DB (1991) Redox viscometry of some Fe-bearing silicate melts. Am Mineral 76:1560-1562

Dingwell DB (1992) Density of some Ti bearing silicate melts and the compositional dependence of the partial molar volume of $\mathrm{TiO}_{2}$. Geochim Cosmochim Acta 56:3403-3407

Dingwell DB, Brearley $M$ (1988) Melt densities in the $\mathrm{CaO}-\mathrm{FeO}-\mathrm{Fe}_{2} \mathrm{O}_{3}-\mathrm{SiO}_{2}$ system and the compositional dependence of the partial molar volume of ferric iron in silicate melts. Geochim Cosmochim Acta 52:2815-2815

Dingwell DB, Virgo D (1987) The effect of oxidation state on the viscosity of melts in the system $\mathrm{Na}_{2} \mathrm{O}-\mathrm{FeO}-\mathrm{Fe}_{2} \mathrm{O}_{3}-\mathrm{SiO}_{2}$. Geochim Cosmochim Acta 51:195-205

Dingwell DB, Webb SL (1989) Structural relaxation in silicate melts and non-Newtonian melt rheology in geological processes. Phys Chem Miner 16:508-516

Dingwell DB, Brearley M, Dickinson JE Jr (1988) Melt densities in the $\mathrm{Na}_{2} \mathrm{O}-\mathrm{FeO}-\mathrm{Fe}_{2} \mathrm{O}_{3}-\mathrm{SiO}_{2}$ system and the partial molar volume of tetrahedrally coordinated ferric iron in silicate melts. Geochim Cosmochim Acta 52:2467-2475

Dingwell DB, Knoche R, Webb SL (1992) Partial molar volumes for $\mathrm{P}_{2} \mathrm{O}_{5}, \mathrm{~B}_{2} \mathrm{O}_{3}$ and $\mathrm{F}_{2} \mathrm{O}_{-1}$ in haplogranitic liquids at magmatic temperatures. Terra Nova Abstr Suppl 1:14

Dingwell DB, Knoche R, Webb SL (1993) The effect of $\mathrm{P}_{2} \mathrm{O}_{5}$ on the viscosity of haplogranitic liquid. Eur J Mineral 5:133-140

Duchesne JC (1984) Massif anorthosites: another partisan review. In: Brown WL (eds) Feldspars and feldspathoids. D. Reidel Publishing Company, Dordrecht, pp 411-433

Dupree R, Holland D, Mortuza MG, Collins JA, Lockyer MWG (1988) An MAS NMR study of network-cation coordination in phosphosilicate glasses. J Non-Cryst Solids 106:403-407

Fudali RF (1965) Oxygen fugacities of basaltic and andesitic magmas. Geochim Cosmochim Acta 29:1063-1075

Gan H, Hess PC (1992) Phosphate speciation in potassium aluminosilicate glasses. Am Mineral 77:495-506

Ghiorso MS, Carmichael ISE (1984) Comment on "Density calculations for silicate liquids. I. Revised method for aluminosilicate compositions" by Bottinga, Weill and Richet. Geochim Cosmochim Acta 48:401-408

Gwinn R, Hess PC (1993) The role of phosphorus in rhyolitic liquids as determined from the homogeneous iron redox equilibrium. Contrib Mineral Petrol 106:129-141

Hara S, Araki T, Ogino K (1988) Phase equilibrium studies in the $\mathrm{FeO}-\mathrm{Fe}_{2} \mathrm{O}_{3}-\mathrm{CaO}$ and $\mathrm{FeO}-\mathrm{Fe}_{2} \mathrm{O}_{3}-2 \mathrm{CaO} . \mathrm{SiO}_{2}$ systems. In: Proc. 2nd Int Symp metall slags fluxes. Metall Soc AIME, Warrendale $\mathrm{PA}, 441-452$

Harrison TM, Watson EB (1984) The behavior of apatite during crustal anatexis: equilibrium and kinetic considerations. Geochim Cosmochim Acta 48:1467-1477

Johnson T, Carmichael ISE (1987) The partial molar volume of $\mathrm{TiO}_{2}$ in multicomponent silicate melts (abstract). Geol Soc Am Abstr Program 19:719

Kilinc A, Carmichael ISE, Rivers ML, Sack RO (1983) The ferric-ferrous ratio of natural silicate liquids equilibrated in air. Contrib Mineral Petrol 83:136-140

Kress VC, Carmichael ISE (1988) Stoichiometry of the iron oxidation reaction in silicate melts. Am Mineral 73:1267-1274

Kushiro I (1975) On the nature of silicate meit and its significance in magma genesis: regularities in the shift of the liquidus boundaries involving olivine, pyroxene, and silica minerals. Am J Sci 275:411-431

Lange RL, Carmichael ISE (1990) Thermodynamic properties of silicate liquids with emphasis on density, thermal expansion and compressibility. In: Nicholls J, Russell JK (eds) Modern methods of igneous petrology: understanding magmatic processes. (Reviews in mineralogy, Vol 24) Mineral Soc AM, Washington,
DC, pp 25-64

Leeman WP, Vitaliano CJ, Prinz M (1976) Evolved lavas from the Snake River plain: Craters of the Moon National Monument, Idaho. Contrib Mineral Petrol 56:35-60

London D, Loomis JL, Huang W, Morgan GB VI (1990) Behavior and effects of phosphorus in the system $\mathrm{Ab}-\mathrm{Or}-\mathrm{Qz}-\mathrm{H}_{2} \mathrm{O}$ at $200 \mathrm{MPa}\left(\mathrm{H}_{2} \mathrm{O}\right)$ (abstract). Geol Soc Am/Mineral Soc AM Program 22: $\mathrm{A} 302$

London D, Morgan VI JB, Babb HA, Loomis JL (1993) Behavior and effects of phosphorus in the system $\mathrm{Na}_{2} \mathrm{O}-\mathrm{K}_{2} \mathrm{O}-\mathrm{Al}_{2} \mathrm{O}_{3}-$ $\mathrm{SiO}_{2}-\mathrm{P}_{2} \mathrm{O}_{5}-\mathrm{H}_{2} \mathrm{O}$ at $200 \mathrm{MPa}\left(\mathrm{H}_{2} \mathrm{O}\right)$. Contrib Mineral Petrol 113:450-465

McBirney AR, Naslund HR (1990) The differentiation of the Skaergaard Intrusion. A discussion of Hunter and Sparks. Contrib Mineral Petrol 104:235-240

Morse SA (1982) A partisan review of Proterozoic anorthosites. Am Mineral 67:1087-1100

Mysen BO (1988) Structure and properties of silicate melts. Elsevier, Amsterdam

Mysen BO (1992) Iron and phosphorus in calcium silicate quenched melts. Chem Geol 98:175-202

Mysen BO, Seifert FA, Virgo D (1980) Structure and redox equilibria of iron bearing silicate melts. Am Mineral 65:867-884

Mysen BO, Virgo D, Neumann ER, Seifert FA (1985) Redox equilibria and the structural states of ferric and ferrous iron in melts in the system $\mathrm{CaO}-\mathrm{MgO}-\mathrm{Al}_{2} \mathrm{O}_{3}-\mathrm{SiO}_{2}-\mathrm{Fe}-\mathrm{O}$ : relationships between redox equilibria, melt structure and liquidus phase equilibria. Am Mineral 70:317-331

Nelson C, Tallant DR (1984) Raman studies of sodium silicate glasses with low phosphate contents. Phys Chem Glasses $25: 31-38$

Philpotts AR (1982) Compositions of immiscible liquids in volcanic rocks. Contrib Mineral Petrol 80:201-218

Richet P (1984) Viscosity and configurational entropy of silicate melts. Geochim Cosmochim Acta 48:471-483

Ryerson FJ (1985) Oxide solution mechanisms in silicate melts: systematic variations in the activity coefficient of $\mathrm{SiO}_{2}$. Geochim Cosmochim Acta 49:637-649

Ryerson FJ, Hess PC (1978) Implications of liquid-liquid distribution coefficients to mineral-liquid partitioning Geochim Cosmochim Acta 42:921-932

Ryerson FJ, Hess PC (1980) The role of $\mathrm{P}_{2} \mathrm{O}_{5}$ in silicate melts. Geochim Cosmochim Acta 44:611-624

Sack RO, Carmichael ISE, Rivers M, Ghiroso MS (1980) Ferricferrous equilibria in natural silicate liquids at 1 bar. Contrib Mineral Petrol 75:369-376

Snyder D, Carmichael ISE, Wiebe RA (1992) Experimental study of liquid evolution in an Fe-rich, layered mafic intrusion: constraints of $\mathrm{Fe}-\mathrm{Ti}$ oxide precipitation on the $T-f_{\mathrm{O}_{2}}$ and $T$ - $\rho$ paths of tholeiitic magmas. Contrib Mineral Petrol 113:73-86

Thornber CR, Roeder PL, Foster JR (1980) The effect of composition on the ferric-ferrous ratio in basaltic liquids at atmospheric pressure. Geochim Cosmochim Acta 44:525-532

Toplis MJ, Libourel G, Carroll MR (1994) The role of phosphorous in crystallisation processes of basalt: An experimental study. Geochim Cosmochim Acta 58:797-810

Visser W, Koster van Groos AF (1979) Effects of $\mathrm{P}_{2} \mathrm{O}_{5}$ and $\mathrm{TiO}_{2}$ on liquid-liquid equilibria in the system $\mathrm{K}_{2} \mathrm{O}-\mathrm{FeO}-\mathrm{Al}_{2} \mathrm{O}_{3}-\mathrm{SiO}_{2}$. Am J Sci 279:970-988

Wager LR, Brown GM (1967) Layered igneous rock. Oliver and Boyd, Edinburgh and London

Watson EB (1976) Two-liquid partition coefficients: experimental data and geochemical implications. Contrib Mineral Petrol $56: 119-134$

Watson EB (1979) Apatite saturation in basic to intermediate magmas. Geophys Res Lett 6:937-940

Wyllie PJ, Tuttle OF (1964) Experimental investigation of silicate systems containing two volatile components. III. The effectsof $\mathrm{SO}_{3}, \mathrm{P}_{2} \mathrm{O}_{5}, \mathrm{HCl}$, and $\mathrm{Li}_{2} \mathrm{O}$, in addition to $\mathrm{H}_{2} \mathrm{O}$, on the melting temperatures of albite and granite. Am J Sci 262:930-939 